\title{
Description of a new species of Pareiorhina (Siluriformes: Neoplecostominae) from Rio São Francisco basin
}

\author{
FÁBIO FERNANDES ROXO ${ }^{1}$, GABRIEL DE SOUZA DA COSTA E SILVA, MAHMOUD MEHANNA ${ }^{1}$ \\ \& CLAUDIO OLIVEIRA ${ }^{1}$ \\ ${ }^{1}$ Laboratório de Biologia e Genética de Peixes, Departamento de Morfologia, IB-UNESP, Campus de Botucatu, 18618-000 Botucatu, \\ SP, Brazil. \\ E-mail: roxoff@hotmail.com.br
}

\begin{abstract}
A new species of Pareiorhina (Neoplecostominae) from the Rio São Francisco basin, Minas Gerais State, Brazil, is described. The new species is distinguished from its congeners (Pareiorhina brachyrhyncha, P. carrancas, and P. rudolphi) by traits related to small plates covered with odontodes randomly distributed on the abdomen, minute lateral cusps on the teeth, pointed odontodes covering pectoral, pelvic, and anal-fin first rays, caudal-fin being completely dark with one hyaline bar, absence of a ridge on the postdorsal surface of trunk, shape of premaxillae and dentaries, and by the absence of odontodes at the ventral tip of the snout.
\end{abstract}

Keywords: cascudinhos, catfish, freshwater, Loricariidae, Neotropical region, South America

\section{Resumo}

Uma nova espécie de Pareiorhina (Neoplecostominae) é descrita da bacia do Rio São Francisco, no Estado de Minas Gerais, Brasil. A nova espécie é distinguida dos seus congêneres (Pareiorhina brachyrhyncha, P. carrancas e P. rudolphi) por caracteres relacionados à presença de pequenas placas coberta por odontódeos distribuídas aleatoriamente pelo abdômen, pequena cúspide lateral nos dentes, odontódeos pontiagudos cobrindo os primeiros raios das nadadeiras peitorais, pélvicas e anal, nadadeira caudal completamente escura com uma listra hialina, ausência de uma quilha na superfície pósdorsal do tronco, formato das pré-maxilas e dentário e pela ausência de odontódeos na extremidade ventral do focinho.

Palavras-chave: cascudinhos, catfish, água doce, Loricariidae, Região Neotropical, América do Sul

\section{Introduction}

In a revision of the family Loricariidae, Gosline (1947) proposed the genus Pareiorhina to include Rhinelepis rudolphi Miranda-Ribeiro, 1911. Also, among the main changes proposed by Gosline was the recognition of Neoplecostominae as a larger group, including Corymbophanes, Delturus, Hemipsilichthys, Kronichthys, Neoplecostomus, Pareiorhaphis, Pareiorhina, Pogonopoma, Pogonopomoides, Canthopomus (=Pseudorhinelepis), Rhinelepis, and Upsilodus. Armbruster (2004), in a phylogenetic analysis, supported the hypotheses that Pareiorhina is a Neoplecostominae and moved it from Hypostominae.

Recently, Chiachio et al. (2008) suggested that Pareiorhina rudolphi and Pareiorhina sp. formed a sister-group to the genus Pseudotocinclus. Cramer et al. (2011) also identified Pareiorhina sp. as a sister group to the genus Pseudotocinclus, but that Pareiorhina brachyrhyncha and $P$. carrancas formed a polytomy with some Neoplecostomus species. Gosline (1947), in the description of the genus Pareiorhina, did not propose any synapomorphies to define the group, but a combination of autopomorphic, plesiomorphic, and derived characters. Bockmann and Ribeiro (2003), in the description of Pareiorhina carrancas, proposed a combination of 